\title{
Cyclic AMP prolongs graft survival by suppressing apoptosis and inflammatory gene expression in acute cardiac allograft rejection
}

\author{
Jie-Young Lee ${ }^{1,2 *}$, Jung Hwan $\mathrm{Kim}^{1,3 *}$, \\ Gibong Chae ${ }^{2}$, Bong-Ki Lee ${ }^{1,4}$, Kwon-Soo Ha, \\ Young-Geun Kwon ${ }^{5}$ and Young-Myeong Kim ${ }^{1,3,6}$ \\ ${ }^{1}$ Vascular System Research Center \\ ${ }^{2}$ Department of Surgery \\ ${ }^{3}$ Department of Molecular and Cellular Biochemistry \\ School of Medicine, Kangwon National University \\ ${ }^{4}$ Cardiovascular Center \\ Kangwon National University Hospital \\ School of Medicine, Kangwon National University \\ Chuncheon 200-701, Korea \\ ${ }^{5}$ Department of Biochemistry \\ College of Life Science and Biotechnology \\ Yonsei University \\ Seoul 120-752, Korea \\ ${ }^{6}$ Corresponding author: Tel, 82-33-250-8831; \\ Fax, 82-33-244-3286; E-mail, ymkim@kangwon.ac.kr \\ *These authors contributed equally to this work. \\ DOI 10.3858/emm.2010.42.1.008
}

Accepted 27 October 2009

Available Online 4 November 2009

Abbreviations: db-cAMP, dibutyryl cAMP; EPR, electron paramagnetic resonance; ICAM-1, intercellular adhesion molecule; NO, nitric oxide; PARP, poly(ADP-ribose)polymerase; POD, post-operative day; qrPCR, quantitative real-time PCR; VCAM-1, vascular cell adhesion molecule-1

\begin{abstract}
This study was designed to investigate the effects of cAMP on immune regulation and apoptosis during acute rat cardiac allograft rejection. We found that the production of immune markers such as inflammatory cytokines (IL-1 $\beta$, IL-6, and TNF- $\alpha$ ), iNOS expression, and nitric oxide (NO) production, was significantly increased in the blood and transplanted hearts of allograft recipients, but not of isograft controls. These increases were effectively suppressed by the administration of the membrane permeable cAMP analog dibutyryl cAMP (db-cAMP). Administration of db-cAMP reduced allograft-induced elevation of several biochemical markers, such as adhesion molecule expression, iron-nitrosyl complex formation, caspase-3 activation, and apoptotic DNA fragmentation in an ani-
\end{abstract}

mal model. Furthermore, treatment of allograft recipients with $\mathrm{db}$-cAMP prolonged median graft survival to 11 days compared with a median graft survival time of 8 days in saline-treated allograft recipients. These results suggest that $\mathrm{db}$-cAMP exerts a beneficial effect on murine cardiac allograft survival by modulating allogeneic immune response and cytotoxicity.

Keywords: apoptosis; cyclic AMP; cytokines; graft rejections; heart transplantation; inflammation; nitric oxide

\section{Introduction}

Cardiac transplantation has become the predominant treatment for improving survival in patients with terminal stages of cardiac failure (Steinman et al., 2001). The success of such surgical intervention is often complicated by acute graft rejection. Numerous studies have investigated the developmental and pathological processes of the cardiac allograft rejection that occurs after transplantation to better understand the cause and to develop methods to prevent or manage rejection; however, acute allograft rejection remains the major obstacle to long-term survival after allograft transplantation (Demetris et al., 1997; Hertz et al., 2005).

Many types of immune process by $T$ cells, dendritic cells, and macrophages are critical for allograft rejection (Kim et al., 2008). Activated immune cells produce a variety of inflammation-associated genes, such as TNF- $\alpha$, IL-1 $\beta$, IL- 6 , interferon- $\gamma$, intercellular adhesion molecule (ICAM-1), vascular cell adhesion molecule-1 (VCAM-1), and iNOS (Langrehr et al., 1992; Lácha et al., 2002; Lattmann et al., 2005). These inflammatory genes have been suggested to be involved in the pathogenesis of immune-associated human diseases, including acute rejection of organ transplantation. Indeed, cytokine production was significantly increased in animals with allograft transplantation compared with isograft control. Therefore, the suppression of cytokine expression by anti-inflammatory drugs ameliorates the development of transplantation rejection (Swenson et al., 1995; Schrepfer et al., 2005). These evidences indicate that allograft rejection is associated with the production of inflammatory cytokines following allograft transplantation. 
After allograft transplantation, elevated cytokine production promotes iNOS expression and NO synthesis (Lancaster et al., 1992). Since a large amount of NO production by iNOS causes cytotoxicity by inactivating the function of critical target proteins associated with ATP biosynthesis (Hibbs et al., 1988) and activating cell death-inducing enzymes (Messmer et al., 1998), it is possible that NO may be an important mediator for myocyte necrosis, ventricular failure, and cardiac dysfunction, which are associated with rejection of the transplanted hearts (Yang et al., 1994). Indeed, inhibition of iNOS activity causes an increase in graft survival (Winlaw et al., 1995). Furthermore, mouse cardiac allografts placed in iNOS-deficient recipients showed reduced cardiac apoptosis compared with those in wild-type controls (Koglin et al., 1999).

The cytotoxic molecules, TNF- $\alpha$ and NO, are capable of triggering apoptotic cell death, via the

A

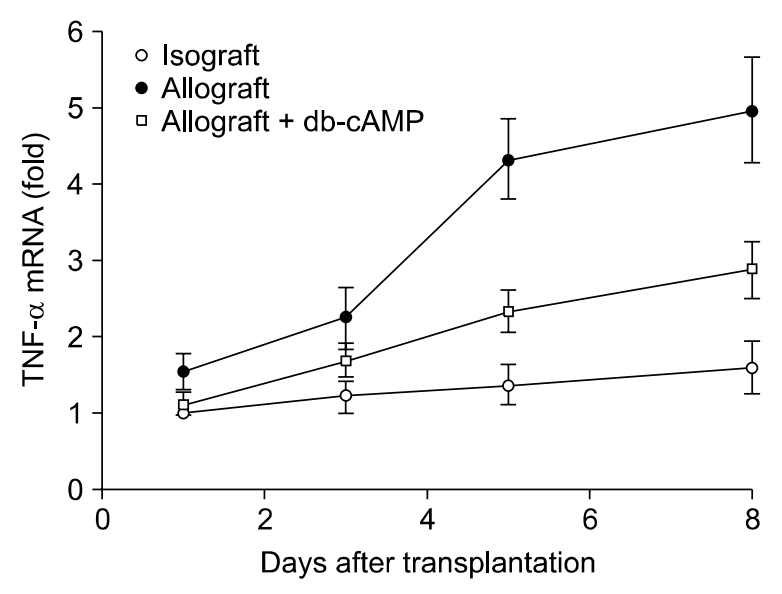

C

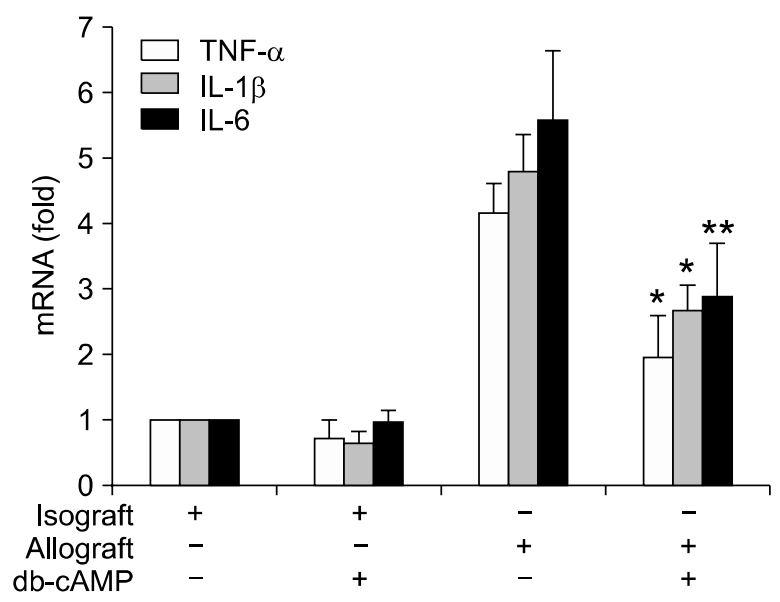

activation of caspase-3, which is a critical executive protease of apoptosis. Numerous studies have demonstrated that apoptosis is significantly increased in transplanted organs undergoing various forms of rejection (Szabolcs et al., 1996; Josien et al., 1998; Koglin et al., 1999). Thus, these cytotoxic molecules are responsible for apoptosis and dysfunction of cardiac myocytes in a cardiac allograft rejection model. These results suggest that cardiac myocyte apoptosis may contribute to the reduced contractile capabilities and a loss of graft function. These descriptive findings indicate that apoptotic cell death is one mechanism that contributes to graft failure during cardiac rejection.

It has been shown that elevation of intracellular cAMP inhibits inflammation-associated gene expression in vitro (Pahan et al., 1997; Mustafa and Olson, 1998), as well as promotes cell survival and cardiac function and contractility (Hanna et al., 1993; Furukawa et al., 1996); however, the func-

\section{B}

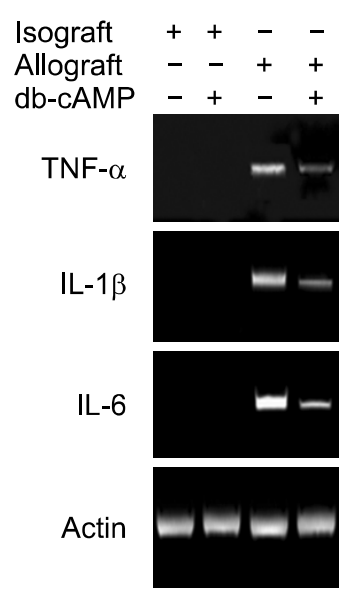

Figure 1. Treatment with $\mathrm{db}$-cAMP inhibits the expression of pro-inflammatory cytokines in transplanted hearts of allograft recipient rats. Transplanted hearts were harvested and total mRNAs were isolated using a Trizol reagent kit. (A) The expression levels of TNF- $\alpha$ were determined by RT-PCR analysis. The TNF- $\alpha$ mRNA levels were normalized by GAPDH and present as relative intensity. Data shown are the mean $\pm \mathrm{SD}(n=4)$. (B) Typical expression patterns of pro-inflammatory cytokines were obtained by RT-PCR in total mRNAs from transplanted hearts on POD 5. (C) The expression levels of pro-inflammatory cytokines were determined by qrPCR analysis. The mRNA levels were calculated from the mRNA ratio of cytokine gene/GAPDH. Data shown are the mean $\pm \mathrm{SD}(n=4)$. ${ }^{*} P<0.05 ;{ }^{* *} P<0.01$ versus non- treated allograft. 
tional effect of cAMP on cardiac allograft rejection, and its action mechanism were not clearly elucidated. We here examined the possible role and effect of the membrane permeable cAMP analog dibutyryl cAMP (db-cAMP) on allogeneic inflammation, caspase-dependent apoptotic cell death, and graft survival in the transplanted hearts of allograft recipient rats. Our data demonstrated that this compound inhibited allograft-mediated immune and biochemical events and prolonged graft survival. These results suggest that $\mathrm{db}$-cAMP plays a regulatory role in allogeneic immune reaction in this model of acute rejection.

\section{Results}

\section{Administration of db-cAMP reduces pro-inflammatory gene expression in cardiac allografts}

Leukocytes and T-cells recruited and trafficked to sites of immune reactions express a variety of cytokines, such as IL-1 $\beta$, IL- 6 , and TNF- $\alpha$, which are involved in the allogeneic immune response and allograft rejection following transplantation (Russell et al., 1995; Lattmann et al., 2005). We first examined whether db-cAMP regulates the expression of TNF- $\alpha$, a typical inflammatory cytokine, in transplanted hearts from allograft recipients. The level of TNF- $\alpha$ mRNA was slightly increased in cardiac allografts on post-operative day (POD) 1-3, highly elevated on POD 5 , and thereafter modera- tely up-regulated up to POD 8 , whereas TNF- $\alpha$ expression was not effectively increased in cardiac isografts. Peritoneal administration of $\mathrm{db}-\mathrm{cAMP}$ significantly reduced an allograft-induced increase in TNF- $\alpha$ expression (Figure 1A). Because of the maximum increase in TNF- $\alpha$ expression at POD 5 , we further determined the effect of $d b$-cAMP on allogeneic immune and biochemical events at this time point. RT-PCR analysis showed that the mRNA levels of pro-inflammatory genes, IL-1 $\beta$, IL-6, and TNF- $\alpha$, were significantly increased in cardiac allografts compared with levels in cardiac isografts, and these increased mRNA levels were significantly suppressed by the administration of db-cAMP (Figure 1B). Similar suppressive effects of $\mathrm{db}$-cAMP on the expression of pro-inflammatory cytokine genes were observed in quantitative data from RT-PCR analysis (Figure $1 \mathrm{C}$ ). These results suggest that db-cAMP inhibits the expression of pro-inflammatory cytokines, which are involved in allograft-induced immune rejection.

\section{Treatment with db-cAMP suppresses adhesion molecule expression in cardiac allografts}

Inflammatory cytokines, IL-1 $\beta, \mathrm{IL}-6$ and TNF-1 $\alpha$, activate the transcription factor $N F-\kappa B$ and subsequently induce the expression of adhesion molecules, including ICAM-1 and VCAM-1, which were relatively correlated both with the degree of $\mathrm{CD}^{+} \mathrm{T}$ cell and leukocyte infiltration and acute allograft rejection (Lácha et al., 2002; Kim et al.,
A

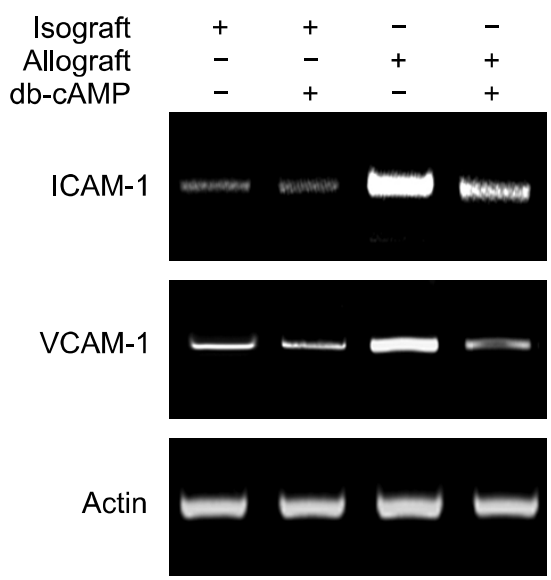

B

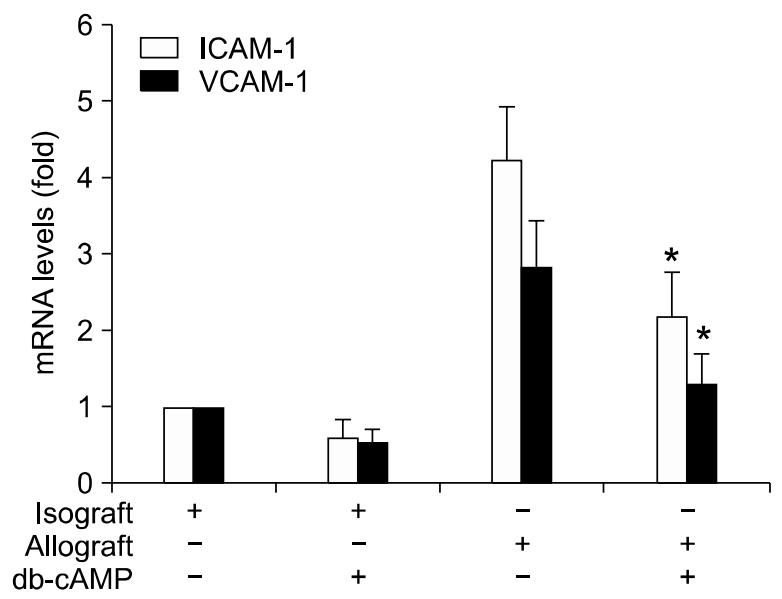

Figure 2. Treatment with db-cAMP inhibits the expression of adhesion molecules in the transplanted hearts of allograft recipient rats. Transplanted hearts were harvested on POD 5 and total mRNAs were isolated using a Trizol reagent kit. (A) Typical expression patterns of ICAM-1 and VCAM- 1 in transplanted hearts were obtained by RT-PCR. (B) The expression levels of ICAM-1 and VCAM-1 were determined by qrPCR analysis, and the mRNA levels were calculated from the mRNA ratio of adhesion molecule gene/GAPDH. Data shown are the mean $\pm \mathrm{SD}(n=4)$. ${ }^{*} P<0.05$ versus non-treated allograft. 
2008). We examined the effect of db-cAMP on the expression of vascular adhesion molecules in cardiac allografts. As expected, the representative data of RT-PCR showed that the expression levels of ICAM-1 and VCAM-1 were significantly increased in cardiac allografts, compared with those in cardiac isografts (Figure 2A). These increases were significantly attenuated by the administration of $\mathrm{db}$-cAMP. Similar results were obtained by quantitative analysis from several RT-PCR data (Figure 2B). These results indicate that cAMP may inhibit the infiltration of immune cells into allografted hearts by suppressing the expression of vascular adhesion molecules.

\section{Treatment with db-cAMP attenuates iNOS expression and NO production in allograft recipients}

Allogeneic immune activation increases $N F-\kappa B$ activity and subsequent induction of rejection-associated genes, including iNOS (Lancaster et al., 1992; Koglin et al., 1999). The expression of iNOS produces a large amount of NO, which may be involved in cytotoxicity and immune rejection (Cai et al., 1995). iNOS expression and NO production were determined by several biochemical analyses, such as RT-PCR, Western blotting, and EPR spectroscopy. RT-PCR analysis revealed a significant increase in iNOS mRNA expression in allografted hearts, but not in isografted hearts, and this increase was effectively inhibited by admi- nistration of db-cAMP (Figure $3 \mathrm{~A}$ ). Similar results were also observed in the regulation of iNOS protein expression by db-cAMP treatment (Figure $3 \mathrm{~B})$. This result suggests that iNOS-mediated NO production in cardiac allografts may be involved in transplantation rejection. Since direct measurement of NO using EPR spectroscopy reveals the formation of heme- and nonheme-nitrosyl signals in allografted tissues (Lancaster et al., 1992; Pieper et al., 2003), we next examined the effect of $\mathrm{db}$-cAMP on iron-nitrosyl complex formation, as an indicator of local interaction of $\mathrm{NO}$ to target proteins, in cardiac allografts. On POD 5, EPR analysis revealed a signal at $g=2.00$, which can result from varying amounts of radicals or as an artifact of sample preparation (Pieper et al., 2003), in transplanted hearts from isograft recipients (Figure $3 \mathrm{C}$ ). In an allograft sample on POD 5 , additional signals were seen at positive deflections at $g=2.04$ and $g$ $=2.08$ and a triplet centered at $g=2.012$ with hyperfine coupling of $17.5 \mathrm{G}$ (Figure 3D). The EPR spectrum overlaps three signal components, such as semiquinone $(g=2.00)$, nonheme iron-dinitrosyl $(g=2.04)$, and heme-nitrosyl signals $(g=2.08$ and $g=2,012$ with triplet splitting of $17.5 \mathrm{G})$. The increased complex signal intensity in the transplanted hearts in allograft recipients was markedly reduced by db-cAMP treatment (Figure $3 C$ ). In addition, the level of nitrite plus nitrate as oxidized products of NO was significantly elevated in the plasma of allograft recipient rats compared with

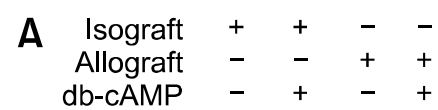

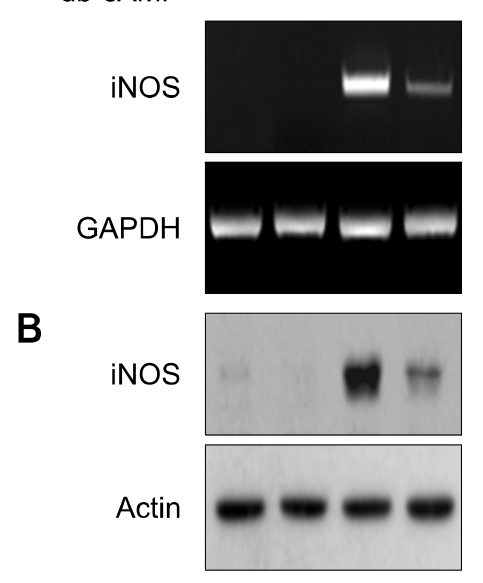

C

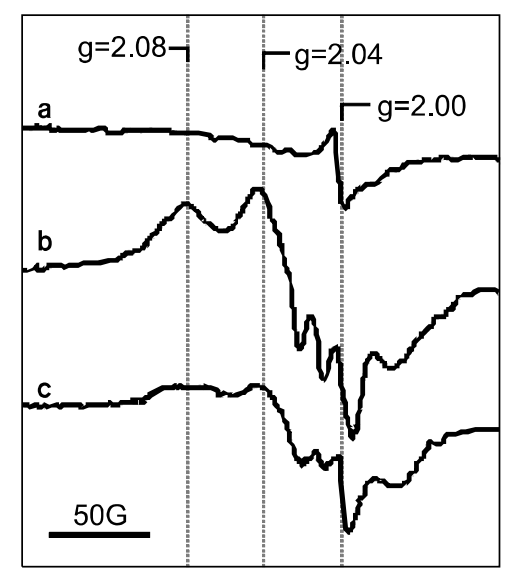

D

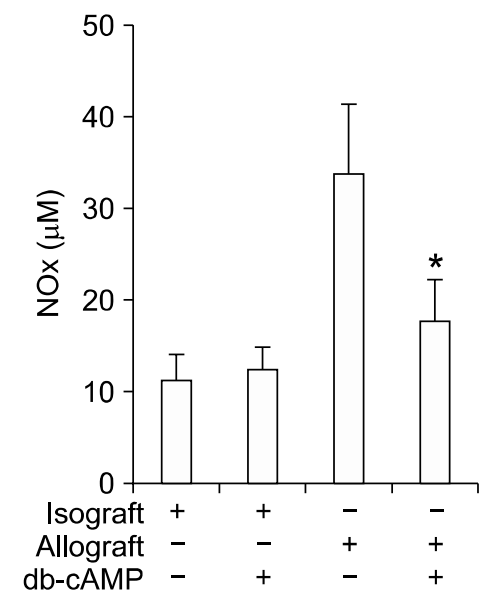

Figure 3. Administration of db-cAMP inhibits iNOS expression, iron-nitrosyl complex formation, and NO production. Transplanted hearts and whole blood were harvested on POD 5. (A) Total mRNAs were isolated, and the levels of iNOS mRNA were determined by RT-PCR. (B) Tissue extracts prepared from transplanted hearts were separated on 10\% SDS-PAGE, and iNOS protein was determined by Western blot analysis. (C) Hearts were harvested on POD 5 and then perfused with ice-cold PBS. Heart tissues were sliced using scissors and homogenized with a Teflon pestle and homogenates were transferred to quartz EPR tubes. EPR spectra were recorded on a Varian E-109 spectrometer at $77 \mathrm{~K}$. a, isograft; b, allograft; c, allograft + db-cAMP. (D) Plasma was prepared from whole blood by centrifugation at $12,000 \times \mathrm{g}$ for $20 \mathrm{~min}$. Plasma levels of nitrite plus nitrate (NOx) were measured by a nitrate reductase-based Griess method. Data shown are the mean $\pm \operatorname{SD}(n=4) .{ }^{*}, P<0.05$ versus non-treated allograft. 
isograft animals as a control, and this increase was effectively reduced by the administration of $\mathrm{db}$-cAMP (Figure 3D). These results indicate that db-cAMP inhibited NO production and iron-nitrosyl complex formation via the suppression of transcriptional iNOS expression in allogeneic heart grafts.

\section{Treatment with db-cAMP inhibits caspase-3 activation and activity in allografted hearts}

It has been shown that the apoptotic protease caspase activation and apoptotic phenomenon have been found in the tissues of allograft rejection (Ichikawa et al., 2000; Kown et al., 2000), suggesting that caspase activation and apoptosis plays a significant role in allograft rejection. We determined whether db-cAMP regulates caspase- 3 activity, which is a main executive protease of the apoptotic process in cardiac allografts. Caspase-3-like activity was initially increased in cardiac allografts on POD 3 and significantly elevated up to POD 8, while this enzyme activity was not altered in isograft controls during the entire experimental period. Moreover, increase in caspase-3-like activity in allografts were significantly suppressed by the administration of db-cAMP (Figure 4A). Since caspase-3 cleaves PARP (116 $\mathrm{kDa})$, a well-characterized biosubstrate, into 85and 31-kDa fragments (Tewari et al., 1995), we investigated this cleavage event in allograft and isograft tissues. When tissue extract from cardiac allograft on POD 5 was incubated with ${ }^{35}$ S-labeled
PARP, fragmentation of PARP was clearly identified by the appearance of an $85-\mathrm{kDa}$ cleavage product, while this cleavage product was not observed in tissue lysates from isografted hearts (Figure 4B). However, the lysates of allografted hearts from rats treated with db-cAMP significantly reduced the generation of the $85-\mathrm{kDa}$ fragment compared with untreated cardiac allografts (Figure 4B). It has been shown that caspase-3 activity is directly dependent on the proteolytic activation to generate a heterodimeric enzyme consisting of the large and small subunits (Thornberry and Lazebnik, 1998). Therefore, we investigated whether the administration of the membrane permeable cAMP analog db-cAMP would regulate caspase-3 activation in cardiac allografts. Western blot analysis showed that the active $17-\mathrm{KDa}$ fragment of caspase-3 was initially generated in allografted hearts on POD 3 and further increased on POD 5, but not in isogeneic recipients, and this increased caspase- 3 activation was significantly inhibited by the administration of db-cAMP (Figure 4C). These results suggest that db-cAMP inhibits caspase-3 activity by suppressing proteolytic activation of pro-caspase-3.

\section{Treatment with db-cAMP blocks DNA fragmentation in allografted hearts}

One consequence of caspase- 3 activation as an apoptosis progress is intranucleosomal DNA fragmentation, which is a hallmark indicator of

A

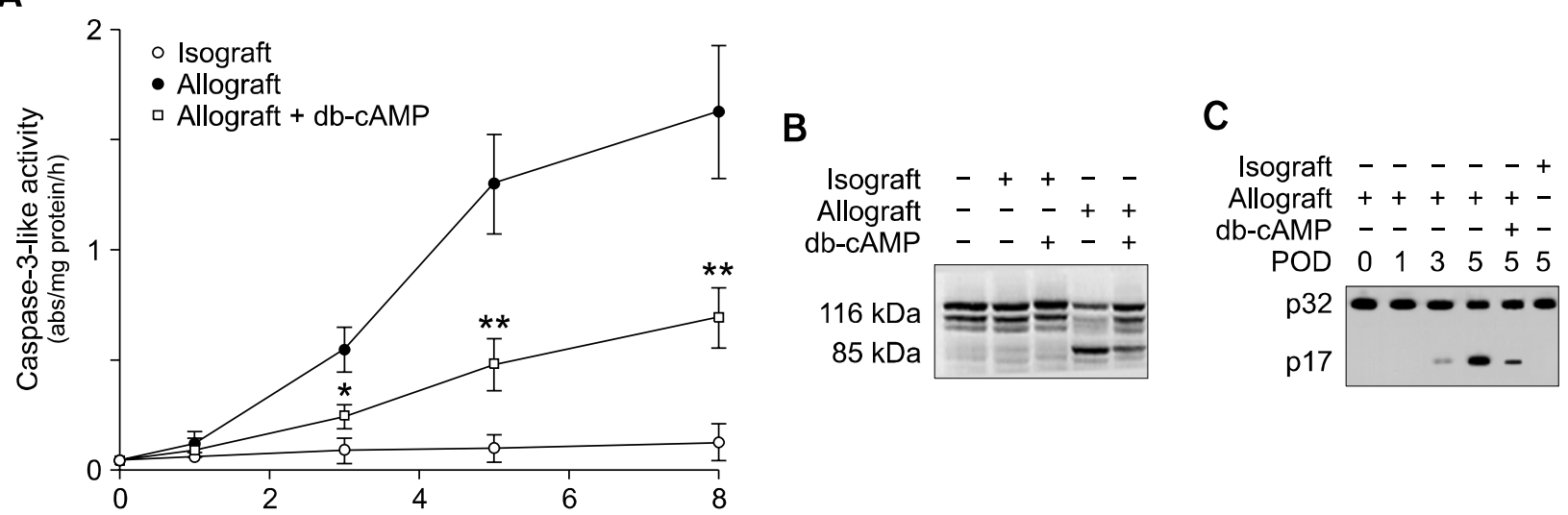

Figure 4. Administration of db-cAMP suppresses caspase-3 activation and activity in cardiac allografts. (A) Transplanted hearts were harvested and homogenized in a 5 -fold volume of lysis buffer. Tissue extract was obtained by centrifugation at $100,000 \times \mathrm{g}$ for $20 \mathrm{~min}$ at $4^{\circ} \mathrm{C}$. Caspase- 3 activity was assayed by colorimetric assay using the chromogenic substrate Ac-DEVD-pNA. Data shown are the mean \pm SD $(n=4)$. ${ }^{*} P<0.05 ;{ }^{* *} P<0.01$ versus non-treated allograft. (B) Transplanted hearts were harvested on POD 5 , and the tissue extracts were prepared by homogenizing and centrifuging at $100,000 \times g$ for 20 min at $4^{\circ} \mathrm{C}$. The tissue extract $(10 \mathrm{mg})$ was incubated with ${ }^{35} \mathrm{~S}$-labelled PARP in a final volume of $15 \mathrm{ml}$ at $37^{\circ} \mathrm{C}$ for $1 \mathrm{~h}$ and then mixed with an equal volume of SDS-sample buffer. PARP cleavage activity was determined by gel electrophoresis and autoradiography. (C) Tissue extracts ( $40 \mu \mathrm{g}$ protein) from transplanted hearts were separated on 14\% SDS-PAGE and transferred onto a nitrocellulose membrane. Caspase-3 activation was determined by Western blot analysis using a polyclonal antibody for caspase-3. 


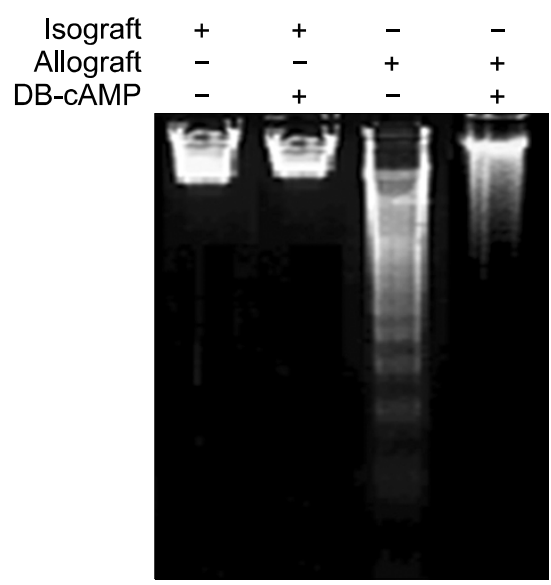

Figure 5. Administration of db-cAMP suppresses DNA fragmentation in cardiac allografts. Transplanted hearts were harvested on POD 5 and homogenized in nucleic acid extraction buffer. DNA was isolated by treatment with proteinase $\mathrm{K}\left(0.5 \mathrm{mg} / \mathrm{ml}, 1 \mathrm{~h}\right.$ at $\left.37^{\circ} \mathrm{C}\right)$ and extraction with mixture of phenol:chloroform. DNA was prepared by ethanol precipitation and ribonuclease A treatment. Samples (50 $\mu \mathrm{g}$ of DNA) were separated on $2 \%$ agarose gel and visualized with UV light.

apoptotic tissue destruction and cell death (Kim et al., 1997). To examine whether db-cAMP would control the tissue destruction of cardiac allograft, DNA fragmentation was determined following DNA extraction from transplanted hearts. Intranucleosomal DNA fragmentation was clearly identified in the DNA extract from cardiac allografts, while this fragmentation was not observed in cardiac isografts (Figure 5). Administration of db-cAMP significantly inhibited the DNA fragmentation observed in allogeneic cardiac donor (Figure 5). These data suggest that db-cAMP can inhibit the functional destruction of allografted hearts by suppressing apoptotic DNA fragmentation, probably via the inhibition of caspase- 3 activation.

\section{Treatment with db-cAMP prolongs cardiac allograft survival}

It has been demonstrated that increases in inflammatory cytokine production, NO synthesis, and caspase-3-dependent apoptosis are highly correlated with functional dysfunction of allografts and allograft survival (Lancaster et al., 1992; Ichikawa et al., 2000). Therefore, we examined whether db-cAMP regulates cardiac allograft survival. Saline-treated recipient mice rejected all cardiac allografts within 9 days with a median survival time of 8 days in an acute rejection rat model, whereas no rejection was observed in cardiac isografts during the experimental period (Figure 6). Administration of db-cAMP prolonged cardiac allograft survival to a median survival time of 11 days (Figure 6). Although not shown, no differences in body weight and health were observed in both saline-treated control and $\mathrm{db}-\mathrm{cAMP}$-treated groups during these experiments; however, cardiac contractility progressively weakened until no contractions could be recognized. These results indicate that db-cAMP may improve cardiac allograft survival by suppressing inflammatory gene expression, NO-mediated cytotoxicity, and caspase-3-dependent apoptotic events.

\section{Discussion}

The present study was undertaken to elucidate the potential effects of the membrane permeable CAMP analog db-cAMP on several allograft rejection indicators, such as pro-inflammatory cytokines, vascular adhesion molecules, caspase- 3 activation, and apoptotic DNA fragmentation, in an acute allograft animal model. We found that db-cAMP significantly suppressed various inflammatory gene expressions, NO production, caspase-3 activation/activity, and DNA fragmentation in cardiac allografts, resulting in the prolonged allograft cardiac survival. These data suggest that db-cAMP and other intracellular cAMP-elevating substances prolong cardiac allograft survival by suppressing apoptotic tissue destruction, allogeneic immune response, and vascular inflammation.

Leukocytes and T cells migrate from the host to allografted organs and produce various inflammatory cytokines, suggesting that the host contributes



Figure 6. Administration of db-cAMP prolongs cardiac allograft survival. After transplantation of isogeneic and allogeneic hearts, rats were intraperitoneally administered db-cAMP (15 mg/kg/day). Cardiac rejection was defined by the cessation of cardiac contraction monitored by transabdominal palpation ( $n=6$ rats/group). 
to the rejection process (Kim et al., 2008). Circulating and intra-graft levels of pro-inflammatory cytokines, such as IL- $6, \mathrm{IL}-1 \beta$, and TNF- $\alpha$, are elevated after experimental organ transplantation as well as in clinical studies (Ichikawa et al., 2000). In fact, treatment with immunosuppressive drugs has been shown to prolong allograft survival via the inhibition of pro-inflammatory cytokine expression and production (Murase et al., 1990; Huang et al., 2003). We here found that the expressional levels of these cytokine genes were elevated in transplanted hearts, in which levels were reduced by treatment with db-cAMP. Furthermore, db-cAMP treatment prolonged cardiac allograft survival. These results suggest that CAMP analogs may improve allograft survival via the suppression of inflammatory cytokine production in response to allograft transplantation.

Inflammatory cytokines elicit NF-кB-dependent gene expression, including ICAM-1, VCAM-1, and iNOS. The vascular adhesion molecules, ICAM-1 and VCAM-1, mediate high-affinity interactions between endothelium and circulating leukocytes and cause penetration of the immune cells into the surrounding tissues. The elevated expression levels of these adhesion molecules in cardiac allograft were significantly reduced by treatment with the immunosuppressive agents, cyclosporine $A$ and FK778, resulting in abolished infiltration of immune cells and prolonged cardiac allograft survival (Schrepfer et al., 2005; Song et al., 2008). Moreover, transplantation of a heart from ICAM-1deficient mice into allogeneic recipients resulted in the significant prolongation of graft survival (Lácha et al., 2002). These observations indicate that the increased expression of ICAM-1 and VCAM-1 act as important factors for the development of cardiac allograft rejection. Cyclic AMP analogs have an anti-leukocyte adhesive action by decreasing the expression of vascular adhesion molecules via the suppression of NF-kB activation, resulting in the inhibition of vascular inflammation (Pober et al., 1993; Ollivier et al., 1996; Rahman et al., 2004). We here found that treatment with db-cAMP resulted in the reduction of ICAM-1 and VACM-1 expression in cardiac allografts. It suggests that $\mathrm{db}$-cAMP blocks the recruitment of inflammatory cells into transplanted allograft organs through the suppression of ICAM-1 and VCAM-1 expression.

Another NF-kB-dependent gene iNOS produces a large amount of NO, a cytotoxic free radical, from L-arginine. Earlier studies have shown a correlation between iNOS-mediated NO production and cardiac myocyte apoptosis in acute cardiac rejection (Lancaster et al., 1992; Szabolcs et al., 1996). Suppression of iNOS expression by immunosu- ppressive strategy can reduce transplantation rejection (Russell et al., 1995). Most importantly, different measures to inhibit NOS activity prevent cardiac injury and prolong graft survival in an animal model (Winlaw et al., 1995; Worrall et al., 1996). In addition, transplantation of normal hearts into iNOS ${ }^{-/-}$mouse recipients significantly reduced iNOS-dependent NO production, histological rejection scores, and apoptotic cell death (Koglin et al., 1999). These observations suggest that iNOS-dependent NO production in transplanted hearts of allograft recipients plays an important role in regulation of acute cardiac rejection.

NO highly interacts with iron-containing proteins, such as heme-containing proteins and iron-sulfurcontaining proteins, to form iron-nitrosyl complex, which can be detected by EPR spectroscopy. In this study, we found EPR spectrum consisting of at least two complex signals in cardiac allografts. The first signal is a typical spectrum of heme-nitrosyl complex that displays a nitrogen hyperfine triplet at $\mathrm{g}=2.012$ with a splitting of 17.5 gauss and $\mathrm{a} \mathrm{g}=$ 2.08 signal (Lancaster et al., 1992; Nakanishi et al., 1998; Pieper et al., 2003). The heme-nitrosyl complex can be generated by two different sources, such as hemoglobin from contaminated erythrocytes and myoglobin of cardiac myocytes in allografts (Nakanish et al., 1998). The other signal was the axial feature at $g=2.04$, which is attributable to the iron-nitrosyl complex of cellular iron-sulfur proteins, and this complex has been suggested to be an intracellular cytotoxic event (Lancaster et al., 1992; Kim et al., 2000). Our results suggest that db-cAMP-mediated suppression of transplantation rejection is due to the inhibition of iNOS-derived NO production and iron-nitrosyl complex formation in cardiac allografts.

Apoptotic cell death or tissue destruction is involved in several pathogenesis of human diseases, and the death of cardiac myocytes via apoptosis in acute cardiac allograft rejection becomes a significant factor leading to contractile dysfunction and heart failure (Laugwitz et al., 2001). It has been shown that caspase-3-like activity and apoptotic cell death were dramatically increased in the transplanted hearts of allograft recipients (Ichikawa et al., 2000). Treatment with caspase inhibitor decreased allograft rejection in a rat model of acute cardiac allograft rejection (Kown et al., 2000). Our results showed that the apoptotic features including caspase-3 activation/activity and DNA fragmentation were significantly elevated in transplanted hearts of allografted recipients, indicating that caspase-3-dependent apoptosis is likely to reduce the function of the allograft organ. In addition, these apoptotic events were inhibited 
following treatment with db-cAMP, suggesting that intracellular cAMP-elevating substances can be used as therapeutic drugs for maintaining the integrity and function of the transplanted allograft heart.

Enhancers of intracellular cAMP (db-cAMP and forskolin) inhibited iNOS expression and subsequent NO production in response to immune stimulants, via inhibition of NF-KB activation, whereas $\mathrm{H} 89$, a specific inhibitor of PKA, stimulated NO production in macrophages and 3T3-L1 cells; however, cAMP can elevate iNOS expression in some other cells, including cardiac myocytes (Ikeda et al., 1996; Mustafa and Olson, 1998). These observations indicate that cAMP differentially regulates iNOS expression, depending on cell types. Our data showed that db-cAMP inhibited iNOS expression and NO production, indicating that a major source of NO production in allograft recipients arises from macrophages which have infiltrated transplanted hearts. On the other hand, the suppressive effect of db-cAMP on NO production may be due to the inhibition of inflammatory cytokines expressed in infiltrated immune cells, probably through the suppression of $N F-\kappa B$ activation. The pathological level of NO production showed to attenuate cardiac contractile function (Balligand et al., 1993). Therefore, improvement of cardiac contractility and allograft survival by db-cAMP in this study may be due to the suppression of NF-kB-dependent increases in inflammatory cytokine and iNOS expression. In addition, CAMP has been demonstrated to inhibit apoptosis by suppressing the activation of multiple caspases ( $\mathrm{Li}$ et al., 2000). We showed that db-cAMP inhibited caspase-3 activation and activity. Thus, the protective effect of db-cAMP on acute cardiac allografts is likely to suppress both caspase- 3 activation and cytotoxic NO production in allograft recipients.

In conclusion, treatment with db-cAMP inhibited increases in various immune and biochemical markers of transplantation rejection in cardiac allografts. These results indicate that db-cAMP promotes cardiac function via the suppression of allogeneic inflammation elicited by infiltrated inflammatory cells and the inhibition of caspase- and NO-mediated cardiac dysfunction in allograft recipients. These effects are likely to be associated with the prolongation of cardiac allograft survival. These results indicate that intracellular cAMP-elevating compounds can be used as a therapeutic drug for improving allograft function and survival, potentially rendering a more therapeutic effect in combination with other agents including immune suppressants.

\section{Methods}

\section{Surgical procedures and animal treatment}

Male Brown Norway (BN, RT1 $\left.{ }^{n}\right)$ and Lewis (LEW, RT1') rats were purchased from Daehan Biolink (Daejeon, Korea). Animals were kept in a specific pathogen-free animal facility and fed a standard diet and water ad libitum. Maintenance of the animals and performance of all experiments conformed to the guidelines of the Council of Animal Care at Kangwon National University. Hearts from 200 to $250 \mathrm{~g}$ naive LEW donors were transplanted to the abdominal aorta and vena cava of 250 to $300 \mathrm{~g} \mathrm{BN}$ recipients or isograft controls to LEW recipients as previously reported (Ono and Lindsey, 1969). Isolated hearts were kept in lactated Ringer's solution (Baxter Healthcare Corp., Chicago, IL) supplemented with $2 \mathrm{mM}$ db-cAMP at $4^{\circ} \mathrm{C}$ for 40 to $60 \mathrm{~min}$. After surgical transplantation of hearts, rats were kept in a specific pathogen-free animal facility and fed a standard diet and water ad libitum. For animal treatment, db-cAMP (MW, 491) was given at $15 \mathrm{mg} / \mathrm{kg} /$ day by single daily intraperitoneal injection during entire the experimental period.

\section{RT-PCR and quantitative real-time PCR (qrPCR)}

Total RNAs from transplanted hearts were isolated using the Trizol reagent kit (Life Technology Inc.). RT-PCR was performed as follows. Five $\mu \mathrm{g}$ of mRNA was converted to cDNA by treatment with 200 units of reverse transcriptase and $500 \mathrm{ng}$ of oligo-dT18 primer in $50 \mathrm{mM}$ Tris- $\mathrm{HCl}(\mathrm{pH}$ 8.3), $75 \mathrm{mM} \mathrm{KCl}, 3 \mathrm{mM} \mathrm{MgCl} 2,10 \mathrm{mM}$ DTT, and $1 \mathrm{mM}$ dNTPs at $42^{\circ} \mathrm{C}$ for $1 \mathrm{~h}$. The reaction was stopped by heating at $70^{\circ} \mathrm{C}$ for $15 \mathrm{~min}$, and $1 \mu \mathrm{l}$ of cDNA mixture was used for enzymatic amplification. PCR was performed in $50 \mathrm{mM} \mathrm{KCl}, 10 \mathrm{mM}$ Tris- $\mathrm{HCl}\left(\mathrm{pH}\right.$ 8.3), $1.5 \mathrm{mM} \mathrm{MgCl}_{2}, 0.2$ $\mathrm{mM}$ dNTPs, 2.5 units of Taq DNA polymerase, and $0.1 \mu \mathrm{M}$ each of primers for several target genes. The PCR reactions were as follows: denaturation, $95^{\circ} \mathrm{C}$ for $1 \mathrm{~min}$; annealing, $55^{\circ} \mathrm{C}$ for $1 \mathrm{~min}$; extension, $72^{\circ} \mathrm{C}$ for 2 min for 25 cycles, followed by $7 \mathrm{~min}$ at $68^{\circ} \mathrm{C}$ for final extension. The RT-PCR products were separated on $1.5 \%$ agarose gel and visualized then with $\mathrm{EtBr}$ staining. Band density was determined by densitometry using a computer-assisted image analyzer. qrPCR was performed using the $A B I$ PRISM 7000 Sequence Detection System (Applied Biosystems) according to the manufacturer's instructions. The $25 \mu \mathrm{l}$ reaction mixture consisted of in iTaq SYBR Green Supermix (Bio-Rad), $0.5 \mu \mathrm{l}$ of cDNA mixture and the appropriate primers $(100 \mathrm{pmol} / \mu \mathrm{l})$. The PCR machine was programmed for the initial step of $2 \mathrm{~min}$ at $50^{\circ} \mathrm{C}$ and $10 \mathrm{~min}$ at $95^{\circ} \mathrm{C}$, followed by 50 cycles of $15 \mathrm{~s}$ at $95^{\circ} \mathrm{C}$ and $1 \mathrm{~min}$ at $60^{\circ} \mathrm{C}$. Relative quantitation of gene expression was determined using comparative threshold multiplex PCR in the same tube after validating that the efficiencies of the target gene and GAPDH products were approximately equal. The primers used in this experiment were as follows; 5 '-CCTCACACTCAGATCATCTTCTCA-3' (sense) and 5'-CTCCTCTGCTTGGTGGTTTGC-3' (antisense) for TNF- $\alpha, 5^{\prime}$-AGTTGCCTTCTTGGGACTGA-3' (sense) and 5'-TGGGTGGTATCCTCTGTGAAG-3' (antisense) for IL-6, 5'-CTGTGGCAGCTACCTATGTCTTG-3' (sense) and 5'-ACACACTAGC- 
AGGTCGTCATCA-3' (antisense) for IL-1 $\beta$, 5'-GATCAATAACCTGAAGCCCG-3' (sense) and 5'-GCCCTTTTTTGCTCCATAAGG-3' (antisense) for iNOS, 5'-AGGTATCCATCCATCCCACA-3' (sense) and 5'-GCCACAGTTCTCAAAGCACA-3' (antisense) for ICAM-1, 5'-CTGACCTGCTGCTCAAGTGATGG-3' (sense) and 5'(antisense) for VCAM-1, and 5'-CCCTCAAGATTGTCAGCAATGC-3' (sense) and 5'-GTCCTCAGTGTACCCAGGAT-3' (antisense) for GAPDH.

\section{Measurements of caspase-3 activation and activity}

Heart tissues were homogenized in a 5-fold volume of lysis buffer (100 mM HEPES, pH 7.4, $140 \mathrm{mM} \mathrm{NaCl}, 0.5 \mathrm{mM}$ PMSF, $5 \mathrm{mg} / \mathrm{ml}$ aprotinin, $5 \mathrm{mg} / \mathrm{ml}$ pepstatin and $10 \mathrm{mg} / \mathrm{ml}$ leupeptin) and then lysed by three freeze-thaw cycles. The tissue extract solution was obtained by centrifugation at $100,000 \times g$ for $20 \mathrm{~min}$ at $4^{\circ} \mathrm{C}$. For assaying caspase- 3 activation, forty $\mu \mathrm{g}$ of protein was separated on $14 \%$ SDS-PAGE and transferred onto a nitrocellulose membrane. Nonspecific binding was blocked with TBS-T (50 mM Tris- $\mathrm{HCl}, \mathrm{pH} 7.5,150 \mathrm{mM} \mathrm{NaCl}, 0.1 \%$ Tween 20) containing $5 \%$ non-fat milk for $1 \mathrm{~h}$ at room temperature. Caspase- 3 activation was determined by Western blot analysis using anti-caspase- 3 polyclonal antibody (Santa Cruz Biotechnology, Santa Cruz, CA) as previously described (Lee et al., 2009). For caspase-3 activity assay, the enzyme reaction was initiated in a 96-well plate by the addition of $200 \mathrm{mg}$ of protein into the reaction buffer (150 $\mu \mathrm{l}, 100 \mathrm{mM}$ HEPES, pH 7.4, 20\% glycerol, $5 \mathrm{mM}$ DTT, and protease inhibitors) containing $400 \mathrm{mM}$ Ac-DEVD-pNA (Alexis Corp., San Diego, CA) as previously described (Kim et al., 1997). The caspase-3-like activity was calculated from the initial velocity by measuring the increased absorbance at $405 \mathrm{~nm}$ every 10 min during incubation at $37^{\circ} \mathrm{C}$. The reaction mixture without enzyme or substrate was used as a control.

\section{Synthesis and cleavage of ${ }^{35} \mathrm{~S}$-labeled poly (ADP-ribose) polymerase (PARP)}

${ }^{35}$ S-labeled PARP was synthesized by coupled in vitro transcription/translation with $\mathrm{T7}$ polymerase in a reticulocyte lysate system (Promega Corp., Madison WI) according to the manufacturer's recommendations (Kim et al., 1997). The labeled proteins were isolated by passage through a Sephadex G-25 column equilibrated with buffer C (10 mM HEPES, pH 7.4, $1.5 \mathrm{mM} \mathrm{MgCl} 2,10 \mathrm{mM} \mathrm{KCl}, 1$ $\mathrm{mM}$ EDTA, $1 \mathrm{mM}$ EGTA, and protease inhibitors). The labeled substrate $(6 \mu \mathrm{l})$ was incubated with the tissue extract $(10 \mu \mathrm{g})$ in a final volume of $15 \mu \mathrm{l}$ at $37^{\circ} \mathrm{C}$ for $1 \mathrm{~h}$ and then mixed with an equal volume of SDS-sample buffer. This mixture was boiled for 3 min and then subjected to electrophoresis on an $8 \%$ SDS-PAGE. After drying, the gel was exposed to $x$-ray film at room temperature.

\section{DNA fragment assay}

Hearts were minced and homogenized in nucleic acid extraction buffer (50 mM Tris- $\mathrm{HCl}, \mathrm{pH} 7.4,1 \mathrm{mM}$ EDTA, and $1 \%$ SDS). DNA was isolated by treatment with proteinase $\mathrm{K}\left(0.5 \mathrm{mg} / \mathrm{ml}, 1 \mathrm{~h}\right.$ at $\left.37^{\circ} \mathrm{C}\right)$ and extraction with mixture of phenol:chloroform. Nucleic acids were precipitated by mixing with $1 / 3$ volume of $3 \mathrm{M}$ sodium acetate and an equal volume of isopropanol. After digesting RNA with RNase $(0.1 \mathrm{mg} / \mathrm{ml})$ at $37^{\circ} \mathrm{C}$ for $1 \mathrm{~h}$, samples $(50 \mu \mathrm{g}$ of DNA) were electrophoresed on a $1.5 \%$ agarose gel in 450 $\mathrm{mM}$ Tris borate + EDTA buffer (pH 8.0). DNA was photographed under visualization with UV light.

\section{Measurement of nitric oxide and electron paramagnetic resonance (EPR) spectroscopy}

After obtaining whole blood in an EDTA-containing tube, plasma was prepared by centrifugation at $12,000 \times g$ for 20 min at $4^{\circ} \mathrm{C}$ and kept at $-20^{\circ} \mathrm{C}$ until use. Plasma levels of total nitrite plus nitrate (NOx, stable oxidized products of NO) were measured using a nitrate reductase-based colorimetric assay kit (Alexis San Diego, CA). Hearts were harvested and perfused with cold PBS to remove blood. Heart tissues were minced into 1-2 mm portions using a scissors. Minced tissues were homogenized in 4 fold volume of PBS on ice in a glass homogenizer with a Teflon pestle for $4 \mathrm{~min}$. The homogenates were placed in a quartz EPR tube and frozen in liquid nitrogen for EPR spectroscopy. EPR examination was performed by an EPR spectrometer (Varian E-109 System) at $77 \mathrm{~K}$, with power at $1 \mathrm{~mW}$, modulation frequency at $100 \mathrm{kHz}$, modulation amplitude at 6.3 gauss, and microwave frequency at 9.44 $\mathrm{GHz}$.

\section{Acknowledgments}

This work was supported by the Korea Science and Engineering Foundation (KOSEF) grant (R11-2001-09000000-0), the Korea Research Foundation Grand founded by the Korea government (MEST) (Regional Research Universities Program/Medical \& Bio-Materials Research Center), and the research grant from the Korea Research Foundation (KRF-2006-312-C00677).

\section{References}

Balligand JL, Ungureanu D, Kelly RA, Kobzik L, Pimental D, Michel T, Smith TW. Abnormal contractile function due to induction of nitric oxide synthesis in rat cardiac myocytes follows exposure to activated macrophage-conditioned medium. J Clin Invest 1993;91:2314-9.

Cai B, Roy DK, Sciacca R, Michler RE, Cannon PJ. Effects of immunosuppressive therapy on expression of inducible nitric oxide synthase (iNOS) during cardiac allograft rejection. Int J Cardiol 1995;50:243-51

Demetris AJ, Murase N, Ye Q, Galvao FHF, Richert C, Saad R, Pham S, Duquesnoy R, Zeevi A, Fung JJ, Starzl TE. Obliterative arteriopathy and Quilty lesions: leukocyte trafficking, microchimerism and the immunolymphatic theory of chronic rejection. Am J Pathol 1997;150:563-78

Furukawa Y, Matsumori A, Hirozane T, Matsui S, Sato Y, Ono $\mathrm{K}$, Sasayama S. Immunomodulation by an adenylate cyclase activator, NKH477, in vivo and in vitro. Clin Immunol Immunopathol 1996;79:25-35 
Hanna AK, Miller J, Liang BT, DiSesa VJ. Reversible contractile dysfunction in reversible experimental cardiac allograft rejection: alterations in the beta-receptor-stimulated adenylylcyclase pathway. J Surg Res 1993;54: 610-5

Hertz MI, Boucek MM, Deng MC, Edwards LB, Keck BM, Kirklin JK, Naftel DC, Rowe AW, Taylor DO, Trulock EP. Scientific Registry of the International Society for Heart and Lung Transplantation: introduction to the 2005 annual reports. J Heart Lung Transplant 2005;24:939-44

Hibbs JB Jr, Taintor RR, Vavrin Z, Rachlin EM. Nitric oxide: a cytotoxic activated macrophage effector molecule. Biochem Biophys Res Commun 1988;157:87-94

Huang WH, Yan Y, De Boer B, Bishop GA, House AK. A short course of cyclosporine immunosuppression inhibits rejection but not tolerance of rat liver allografts. Transplantation 2003;75:368-74

Ichikawa N, Demetris AJ, Starzl TE, Ye Q, Okuda T, Chun HJ, Liu K, Kim YM, Murase N. Donor and recipient leukocytes in organ allografts of recipients with variable donor-specific tolerance: with particular reference to chronic rejection. Liver Transpl 2000;6:686-702

Ikeda U, Yamamoto K, Ichida M, Ohkawa F, Murata M, limura O, Kusano E, Asano Y, Shimada K. Cyclic AMP augments cytokine-stimulated nitric oxide synthesis in rat cardiac myocytes. J Mol Cell Cardiol 1996;28:789-95

Josien R, Müschen M, Gilbert E, Douillard P, Heslan JM, Soulillou JP, Cuturi MC. Fas ligand, tumor necrosis factor-alpha expression, and apoptosis during allograft rejection and tolerance. Transplantation 1998;66:887-93

Kim IK, Bedi DS, Denecke C, Ge X, Tullius SG. Impact of innate and adaptive immunity on rejection and tolerance. Transplantation 2008;86:889-94

Kim YM, Talanian RV, Billiar TR. Nitric oxide inhibits apoptosis by preventing increases in caspase-3-like activity via two distinct mechanisms. J Biol Chem 1997;272: 31138-48

Kim YM, Chung HT, Simmons RL, Billiar TR. Cellular non-heme iron content is a determinant of nitric oxide-mediated apoptosis, necrosis, and caspase inhibition. J Biol Chem 2000;275:10954-61

Koglin J, Granville DJ, Glysing-Jensen T, Mudgett JS, Cathry CM, McManus BM, Russell, M.E. Attenuated acute cardiac rejection in $\mathrm{NOS}^{-1-}$ recipients correlates with reduced apoptosis. Circulation 1999;99:836-42

Kown MH, Van der Steenhoven T, Blankenberg FG, Hoyt G, Berry GJ, Tait JF, Strauss HW, Robbins RC. Zinc-mediated reduction of apoptosis in cardiac allografts. Circulation 2000;102:III228-32

Lácha J, Bushell A, Smetana K, Rossmann P, Pribylová P, Wood K, Malý P. Intercellular cell adhesion molecule-1 and selectin ligands in acute cardiac allograft rejection: a study on gene-deficient mouse models. J Leukoc Biol 2002; $71: 311-8$

Lancaster JR Jr, Langrehr JM, Bergonia HA, Murase N, Simmons RL, Hoffman RA. EPR detection of heme and nonheme iron-containing protein nitrosylation by nitric oxide during rejection of rat heart allograft. J Biol Chem 1992; 267:10994-8

Langrehr JM, Murase N, Markus PM, Cai X, Neuhaus P, Schraut W, Simmons RL, Hoffman RA. Nitric oxide production in host-versus-graft graft-versus-host reactions in the rat. J Clin Invest 1992;90:679-83

Lattmann T, Hein M, Horber S, Ortmann J, Teixeira MM, Souza DG, Haas E, Tornillo L, Münter K, Vetter W, Barton M. Activation of pro-inflammatory and anti-inflammatory cytokines in host organs during chronic allograft rejection: role of endothelin receptor signaling. Am J Transplant 2005;5:1042-9

Laugwitz KL, Moretti A, Weig HJ, Gillitzer A, Pinkernell K, Ott T, Pragst I, Stödele C, Seyfarth M, Schömig A, Ungerer M. Blocking caspase-activated apoptosis improves contractility in failing myocardium. Hum Gene Ther 2001;12:2051-63

Lee SJ, Lee JK, Maeng YS, Kim YM, Kwon YK. Langerhans cell protein 1 (LCP1) binds to PNUTS in the nucleus: implications for this complex in transcriptional regulation. Exp Mol Med 2009;41:189-200

Li J, Yang S, Billiar TR. Cyclic nucleotides suppress tumor necrosis factor alpha-mediated apoptosis by inhibiting caspase activation and cytochrome $c$ release in primary hepatocytes via a mechanism independent of Akt activation. J Biol Chem 2000;275:13026-34

Messmer UK, Reimer DM, Brüne B. Protease activation during nitric oxide-induced apoptosis: comparison between poly(ADP-ribose) polymerase and U1-70kDa cleavage. Eur J Pharmacol 1998;349:333-43

Murase N, Kim DG, Todo S, Cramer DV, Fung JJ, Starzl TE. Suppression of allograft rejection with FK506. I. Prolonged cardiac and liver survival in rats following short-course therapy. Transplantation 1990;50:186-9

Mustafa SB, Olson MS. Expression of nitric-oxide synthase in rat Kupffer cells is regulated by cAMP. $\mathrm{J}$ Biol Chem 1998;273:5073-80

Nakanishi AL, Roza AM, Adams MB, Seibel R, Moore-Hilton G, Kalyanaraman B, Pieper GM. Electron spin resonance analysis of heme-nitrosyl and reduced iron-sulfur centered complexes in allogeneic, heterotopic cardiac transplants: effects of treatment with pyrrolidine dithiocarbamate. Free Radic Biol Med 1998;25:201-7

Ollivier V, Parry GC, Cobb RR, de Prost D, Mackman N. Elevated cyclic AMP inhibits NF- $\kappa B$-mediated transcription in human monocytic cells and endothelial cells. J Biol Chem 1996;271:20828-35

Ono K, Lindsey ES. Improved technique of heart transplantation in rats. J Thorac Cardiovasc Surg 1969;57: 225-9

Pahan K, Namboodiri AM, Sheikh FG, Smith BT, Singh I. Increasing cAMP attenuates induction of inducible nitric-oxide synthase in rat primary astrocytes. J Biol Chem 1997;272:7786-91

Pieper GM, Halligan NL, Hilton G, Konorev EA, Felix CC, Roza AM, Adams MB, Griffith OW. Non-heme iron protein: 
a potential target of nitric oxide in acute cardiac allograft rejection. Proc Natl Acad Sci USA 2003;100:3125-30

Pober JS, Slowik MR, De Luca LG, Ritchie AJ. Elevated cyclic AMP inhibits endothelial cell synthesis and expression of TNF-induced endothelial leukocyte adhesion molecule-1, and vascular cell adhesion molecule-1, but not intercellular adhesion molecule-1. J Immunol 1993;150:5114 -23

Rahman A, Anwar KN, Minhajuddin M, Bijli KM, Javaid K, True AL, Malik AB. cAMP targeting of p38 MAP kinase inhibits thrombin-induced NF- $\mathrm{KB}$ activation and ICAM-1 expression in endothelial cells. Am J Physiol Lung Cell Mol Physiol 2004;287:1017-24

Russell ME, Wallace AF, Hancock WW, Sayegh MH, Adams DH, Sibinga NE, Wyner LR, Karnovsky MJ. Upregulation of cytokines associated with macrophage activation in the Lewis-to-F344 rat transplantation model of chronic cardiac rejection. Transplantation 1995;59: 572-8

Schrepfer S, Deuse T, Schäfer H, Reichenspurner H. FK778, a novel immunosuppressive agent, reduces early adhesion molecule up-regulation and prolongs cardiac allograft survival. Transpl Int 2005;18:215-20

Song G, Zhao X, Xu J, Song H. Increased expression of intercellular adhesion molecule-1 and vascular cell adhesion molecule-1 in rat cardiac allografts. Transplant Proc 2008; 40:2720-3

Steinman TI, Becker BN, Frost AE, Olthoff KM, Smart FW, Suki WN, Wilkinson AH. Clinical Practice Committee, American Society of Transplantation. Guidelines for the referral and management of patients eligible for solid organ transplantation. Transplantation 2001;71:1189-204

Swenson JM, Fricker FJ, Armitage JM. Immunosuppression switch in pediatric heart transplant recipients: cyclosporine to FK 506. J Am Coll Cardiol 1995;25:1183-8

Szabolcs M, Michler RE, Yang X, Aji W, Roy D, Athan E, Sciacca RR, Minanov OP, Cannon PJ. Apoptosis of cardiac myocytes during cardiac allograft rejection: relation to induction of nitric oxide synthase. Circulation 1996;94: 1665-73

Tewari M, Quan LT, O'Rourke K, Desnoyers S, Zeng Z, Beidler DR, Poirier GG, Salvesen GS, Dixit VM. Yama/CPP32 beta, a mammalian homolog of CED-3, is a CrmA-inhibitable protease that cleaves the death substrate poly(ADP-ribose) polymerase. Cell 1995;81:801-9

Thornberry NA, Lazebnik Y. Caspases, enemies within. Science. 1998;281:1312-6

Winlaw DS, Schyvens CG, Smythe GA, Du ZY, Rainer SP, Lord RS, Spratt PM, Macdonald PS. Selective inhibition of nitric oxide production during cardiac allograft rejection causes a small increase in graft survival. Transplantation 1995;60:77-82

Worrall NK, Misko TP, Sullivan PM, Hui JJ, Ferguson TB Jr. Inhibition of inducible nitric oxide synthase attenuates established acute cardiac allograft rejection. Ann Thorac Surg 1996;62:378-85

Yang X, Chowdhury N, Cai B, Brett J, Marboe C, Sciacca RR, Michler RE, Cannon PJ. Induction of myocardial nitric oxide synthase by cardiac allograft rejection. J Clin Invest 1994; 94:714-21 